\title{
Cenozoic synthem stratigraphic architecture of the SE Brazilian shelf and its global eustatic context: evidence from the Pelotas Basin (offshore Brazil)
}

\author{
Geise de Santana dos Anjos Zerfass ${ }^{1 *}$, Dmitry A. Ruban ${ }^{2,3}$, \\ Farid Chemale Jr. ${ }^{4}$ \& Henrique Zerfass ${ }^{5}$
${ }^{1}$ PETROBRAS/CENPES/PDGEO/BPA, Av. Horácio Macedo, 950, prédio 20, 1100, Cidade Universitária, Ilha do Fundão, 21941-915 Rio de Janeiro, RJ, Brazil; e-mail: geise.zerfass@petrobras.com.br 40, Rostov-na-Donu, 344090, Russia; e-mail: ruban-d@mail.ru, ruban-d@rambler.ru
${ }^{3}$ International Agency for Minerals Policy ('MinPol'), Austria Postal 0446, 70910-900 Brasília DF, Brazil; e-mail: fchemale@unb.br
${ }^{5}$ PETROBRAS/RH/UP/ECTEP/PCGEO, Rua Ulysses Guimarães 565, 20211-225 Rio de Janeiro, RJ, Brazil; e-mail: henrique.zerfass@petrobras.com.br *corresponding author \\ 2 Department of Mineralogy and Petrography, Institute of Earth Sciences, Southern Federal University, Zorge Street \\ ${ }^{4}$ Instituto de Geociências, Universidade de Brasília, Campus Universitário Darcy Ribeiro ICC - Ala Central, Caixa
}

\begin{abstract}
The Pelotas Basin, located on the SE Brazilian shelf, has evolved since the Aptian. Stratigraphical data from the basin can be used for delineation of the unconformity-bounded units (synthems) on the shelf, which is a first step towards a full understanding of its stratigraphic architecture, evolution, and hydrocarbon potential. Hiatuses in the Cenozoic succession of the Pelotas Basin are established with both biostratigraphic (planktonic foraminifers and calcareous nannofossils) and isotopic $\left({ }^{87} \mathrm{Sr} /{ }^{86} \mathrm{Sr}\right.$ ) data. The seven recognised hiatuses are dated respectively as (1) Palaeocene (Danian-Thanetian), (2) Palaeocene/Eocene boundary (Thanetian-Ypresian), (3) Eocene (Ypresian-Lutetian), (4) Eocene-Oligocene (Lutetian-Rupelian), (5) early-late Oligocene (Rupelian-Chattian), (6) early Miocene (Aquitanian-Burdigalian), and (7) middle-late Miocene (Serravallian-Tortonian). These intervals between the hiatuses are correlated with those of the Santos and Campos Basins north from the Pelotas Basin.

The breaks in sedimentation that these basins have in common occurred (1) at the Palaeocene-Eocene and (2) Eocene-Oligocene transitions, (3) in the early Miocene, and (4) in the middle-late Miocene. These main unconformities outline five synthems on the SE Brazilian shelf, viz. the SEBS-1 (Palaeocene), SEBS-2 (Eocene), SEBS-3 (Oligocene), SEBS-4 (early-middle Miocene) and SEBS-5 (late Miocene-Holocene). The above unconformities are correlated with those established in the Cenozoic sedimentary successions of different regions such as Western Siberia, Arabia, NW and NE Africa, peninsular India, S Australia, the Gulf of Mexico, NW Europe, and South Africa.

The only regional unconformity, near the Oligocene/Miocene boundary, coincides with the nearly-global sedimentation break. The latter was resulted from a climatic event, i.e., the 'Mi-1 glaciation'. Thus, a eustatic origin is supposed for this regional unconformity. The other regional unconformities also correspond to global sea-level falls (probably with an exception for the Palaeocene/Eocene surface), which suggests that global eustatic movements controlled the development of the regional synthem architecture.
\end{abstract}

Key words: synthem, Pelotas Basin, Brazilian continental shelf, Cenozoic 


\section{Introduction}

Unconformity-bounded units can help deciphering the regional stratigraphic architecture and global correlations of its particular elements. The basic unconformity-bounded unit is the synthem, as defined by Chang (1975) and adopted as a formal stratigraphic unit (Salvador, 1987, 1994). Synthems have remained in use until now (e.g., Sacchi et al., 1999; Ruban et al., 2009; Ielpi, 2012), because establishing synthems are complementary to the use of sequences (see Ruban, 2007; Ruban et al., 2009). Although modern changes in the very essence of sequence stratigraphy (Catuneanu, 2006; Catuneanu et al., 2009, 2010, 2011) may dictate further revision of the relationships between synthems and sequences (cf. Murphy \& Salvador, 1998; Salvador, 2003), it is evident that synthems may be useful as non-genetic units and as units that are independent of our understanding of basin-scale sedimentary processes (Ruban, 2007). In other words, synthems and sequences differ, and they are not alternatives for each other. The establishment of both types of units may be mutually helpful.

The SE Brazilian shelf is an important hydrocarbon province, containing the most important reserves of Brazil as well as the major current production sites (Fig. 1). In this region, the Cenozoic sedimentary successions of the Pelotas, Santos, and Campos Basins are interrupted by a series of main unconformities. Despite a huge amount of published (Koutsoukos, 1982; Gomide, 1989; Anjos \& Carreño, 2004; Bueno et al., 2007) and unpublished (Fontana, 1996; Anjos, 2004; Anjos-Zerfass, 2009) data on the stratigraphy and evolution of the Pelotas Basin, it remains less intensively studied than the other basins. More detailed examination of the sedimentary records from the Pelotas Ba$\sin$ is therefore desirable, also because of the current needs of hydrocarbon exploration. In contrast, the Santos and Campos Basins have been studied very well since the 1970s, due to their important hydrocarbon occurrences. The litho- and biostratigraphical knowledge of the latter basins is rather consistent (the database established by the oil companies is, however, not available for researchers).
The published stratigraphic framework (Moreira et al., 2007; Winter et al., 2007) can be discussed for comparison of the Cenozoic sedimentary successions of the Pelotas Basin and the other basins on the SE Brazilian shelf. In the case of the Pelotas Basin, where no outcrops of strata older than Quaternary are present, and where the scarce drill-wells yield only biostratigraphical and lithostratigraphical data obtained from cutting samples (Fig. 2), unconformity-bounded units become useful for correlation. This is because biostratigraphical and isotope methods for determining relative ages allow the recognition of important hiatuses, which can be correlated with regional or global unconformities. In contrast, the highly informative sequence-stratigraphy deals with stacking patterns, so that it needs integrated seismic, outcrop and drill-core data, which are not jointly available for the Pelotas Basin.

The objectives of the present contribution are (1) to establish Cenozoic hiatuses in the Pelotas Basin, (2) to outline synthems and to trace them over the SE Brazilian shelf, and (3) to put the synthem stratigraphic architecture thus obtained into a global eustatic context. The available biostratigraphical (planktonic foraminifers, calcareous nannofossils), lithostratigraphical, and isotope-stratigraphical $\left({ }^{87} \mathrm{Sr} /{ }^{86} \mathrm{Sr}\right)$ datasets (see details below), also obtained from new studies, are employed for these purposes.

\section{Geological setting}

The southern border of the Pelotas Basin is located off the coast of Uruguay (Fig. 1). The basin is located between $28^{\circ} 40^{\prime} \mathrm{S}$ and $34^{\circ} \mathrm{S}$, between the Florianópolis and São Paulo Highs (Brazil) in the North and the Polonio High and the Chuí Lineament (Uruguay) in the South (Kowsmann et al., 1974; Bassetto et al.; 2000; Rosa, 2007; Dias, 2009). The Florianópolis and São Paulo Highs are of volcanic origin, corresponding to the initial phases of the Pelotas and Santos Basins (late Aptian) (Dias, 2009). The Polonio High is a feature of the Precambrian basement of the Uruguayan Shield. The surface area of the basin is about $210,000 \mathrm{~km}^{2}$ off- 

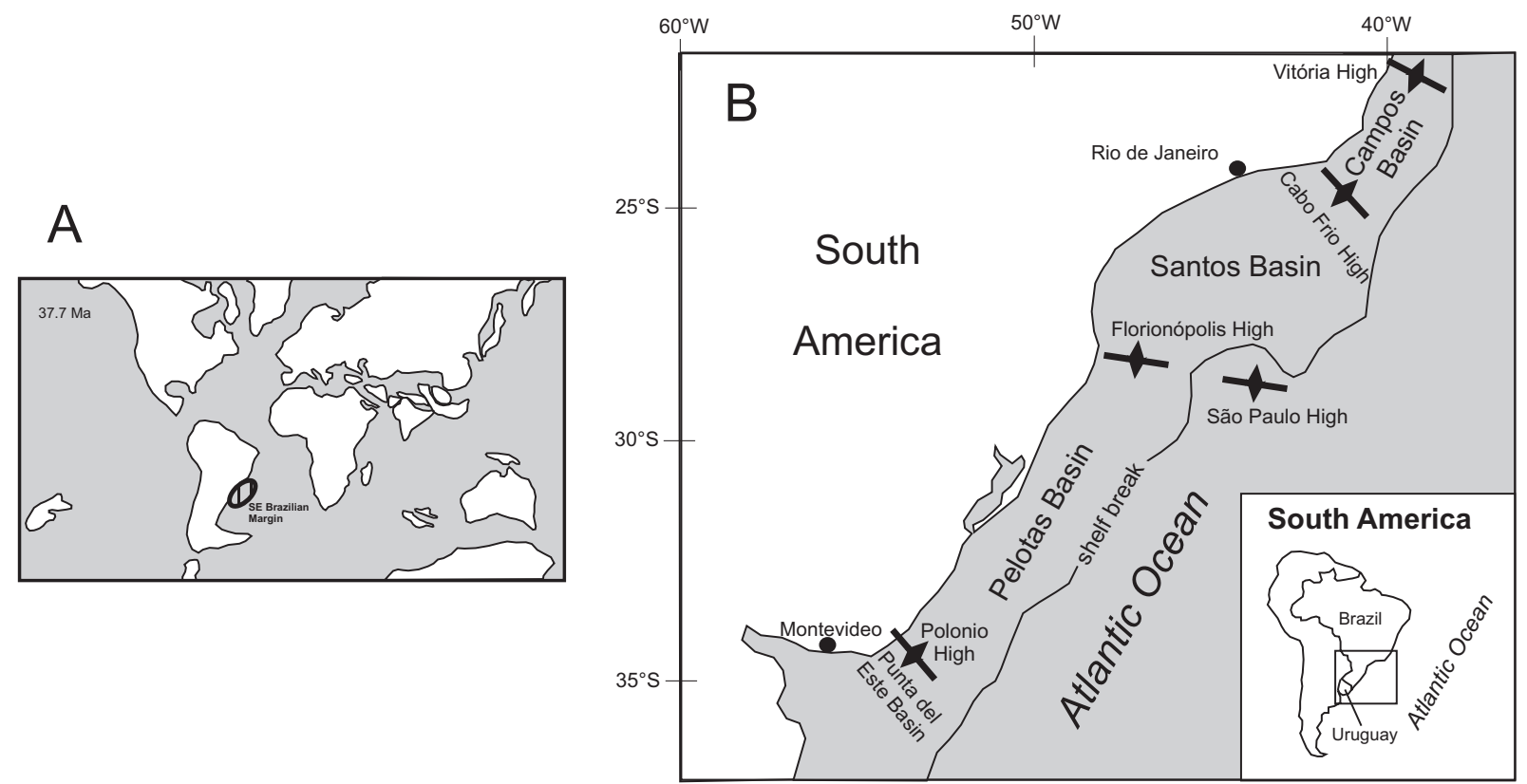

Fig. 1. Location of the area under study.

A: Location during the Eocene (simplified from scotese.com); B: Present-day location of the Pelotas, Santos, and Campos Basins (modified from Soto et al., 2011).

shore until the isobath of 2,000 m, with 40,000 $\mathrm{km}^{2}$ onshore, where only Quaternary deposits are cropping out (Figs 1-2). The maximum thickness of the sedimentary succession, from the Aptian to the Holocene, is about 12,000 m (Fontana, 1996). Like the other basins of the SE Brazilian shelf, the evolution of the Pelotas Basin began with the break-up of Gondwana and the opening of the South Atlantic, i.e., since the Aptian (Ojeda, 1981, Asmus \& Baisch, 1983, Conceição et al., 1988, Chang et al. 1992, Cainelli \& Mohriak, 1999). The Cenozoic succession was deposited on a true passive margin during the drift phase.

The Santos Basin is located to the north from the Florianópolis High, i.e., between the latitudes $23^{\circ}$ and $28^{\circ} \mathrm{S}$. Its northern border is marked by the Cabo Frio High (Fig. 1). The Campos Basin is located north of the Santos Basin, separated from the Espírito Santo Basin by the Vitória High (Fig. 1). Both structural highs are features of the basement, which are Brasiliano-Pan-African (i.e., Neoproterozoic) in age. The entire succession of the both basins is Neocomian to Holocene in age (Moreira et al., 2007; Winter et al., 2007).

The Cenozoic successions of the SE Brazilian shelf reflect a major regressive episode, when a clastic wedge prograded seawards. There is a time-persistent lateral variation from coastal to deep-marine environments on a pure siliciclastic or a mixed platform. The coastal systems are sandy fluvial and deltaic units, namely the Cidreira Formation in the Pelotas Basin (Bueno et al., 2007), the Ponta Aguda Formation in the Santos Basin (Moreira et al., 2007), and the Emborê Formation in the Campos Basin (Winter et al., 2007). Shallow-marine carbonates are present in the Santos and Campos Basins, where they compose the Iguape and Emborê Formations, respectively (Moreira et al., 2007; Winter et al., 2007). The deep-marine deposits are pelagic mudstones, namely the Imbé (Pelotas Basin), Marambaia (Santos Basin), and Ubatuba (Campos Basin) Formations (Bueno et al., 2007; Moreira et al., 2007; Winter et al., 2007). Deepmarine sandstone bodies are associated with density flows deposited close to the continental slope. These deposits are more important in the Santos and Campos Basins, where the submarine channel-lobe complexes constitute important reservoirs.

\section{Materials and methods}

The chronostratigraphy of the Pelotas Basin is based on biostratigraphical and isotope 


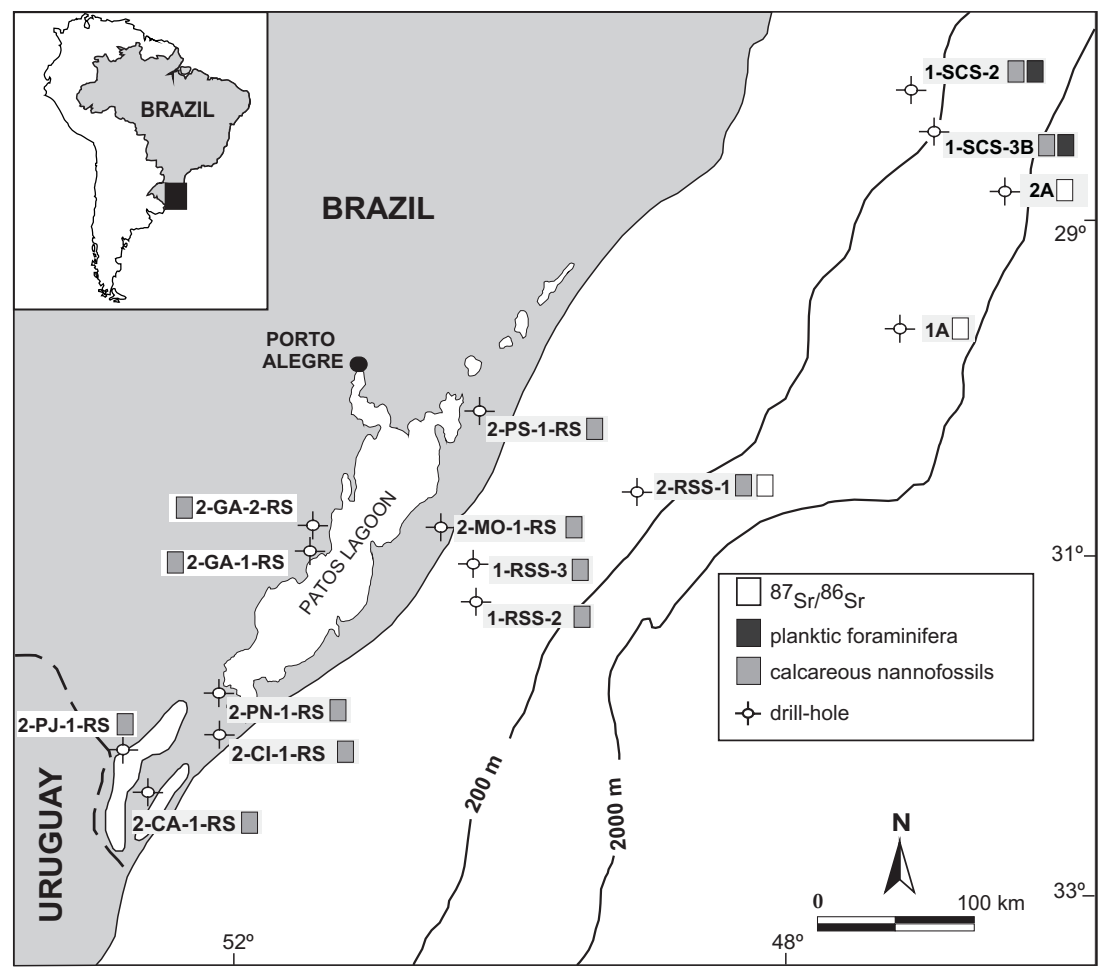

Fig. 2. Location map of the Pelotas Basin with wells and data obtained. data which were obtained from exploratory oil wells drilled by Petrobras (Fig. 2). In terms of biostratigraphy, the data were taken from two studies of planktonic foraminifers (Koutsoukos, 1982; Anjos, 2004) that employed cut samples of two wells in the northern part of the basin. The work by Koutsoukos (1982) included the entire Cenozoic succession, whereas Anjos (2004) dealt with the Miocene-Pliocene interval. Additionally, calcareous nannofossils of the entire Cenozoic section onshore and offshore were studied by Gomide (1989). The above authors pointed out some hiatuses in the stratigraphic record. However, as each author adopted a different zonation scheme, the hiatuses do in many cases not coincide.

Relative ages inferred from ${ }^{87} \mathrm{Sr} /{ }^{86} \mathrm{Sr}$ curves of foraminifer shells from two wells drilled by Petrobras (Anjos-Zerfass, 2009; Fig. 2) were used to reinforce the identification of important hiatuses which are marked by shifts in age throughout the section. These wells, 1A, 2A and 2-RSS-1, are located in the central part of the basin. The drill-hole 1-A section ranges from the Eocene to the middle Miocene and the $2 \mathrm{~A}$ section ranges from the Eocene to the Pliocene; from drill-hole 1-RSS-2, data were collected from a short interval of a drill-core recovering the early/middle Miocene transition. This technique enabled accurate determination of the relative age, with the best resolution registered at steeped segments of the standard curve with the best temporal resolution achieved in the intervals from late Eocene to middle Miocene and from late Pliocene to Pleistocene (Elderfield, 1986; Hess et al., 1986; Hodell et al., 1991; Hodell \& Woodruff, 1994; Oslick et al., 1994).

The synthem stratigraphic approach employed for the purpose of the present analysis is based on recommendations of the International Commission on Stratigraphy (Salvador, 1994). Additionally, the study by Ruban et al. (2009) is used as a kind of template. Identification of hiatal surfaces permits to outline the more or less uniform sedimentary packages in between, whereas various stratigraphical techniques (see above) allow to establish their age. The synthem stratigraphic architecture thus obtained is ready for further interregional correlations within the framework of modern chronostratigraphy (Ogg et al., 2008). The present study involves a three-step approach. First, surfaces in the Cenozoic succession of the Pelotas Basin representing a hiatus are registered on the basis of the available (both published 
and new) data. Then these surfaces are correlated across the SE Brazilian shelf, comparing the sedimentary successions of the Pelotas, Santos, and Campos Basins. Finally, the intervals between the hiatuses that the three basins have in common are suggested as regional synthem boundaries that may be further discussed in a global context. Only those surfaces that reflect more or less significant sedimentation breaks and can be interpreted as unconform- ities have been used for the purposes of the present contribution.

\section{Cenozoic surfaces representing hiatuses in the Pelotas Basin}

The analysis of the Cenozoic biostratigraphical framework of the Pelotas Basin leads us to the identification of five hiatuses in the

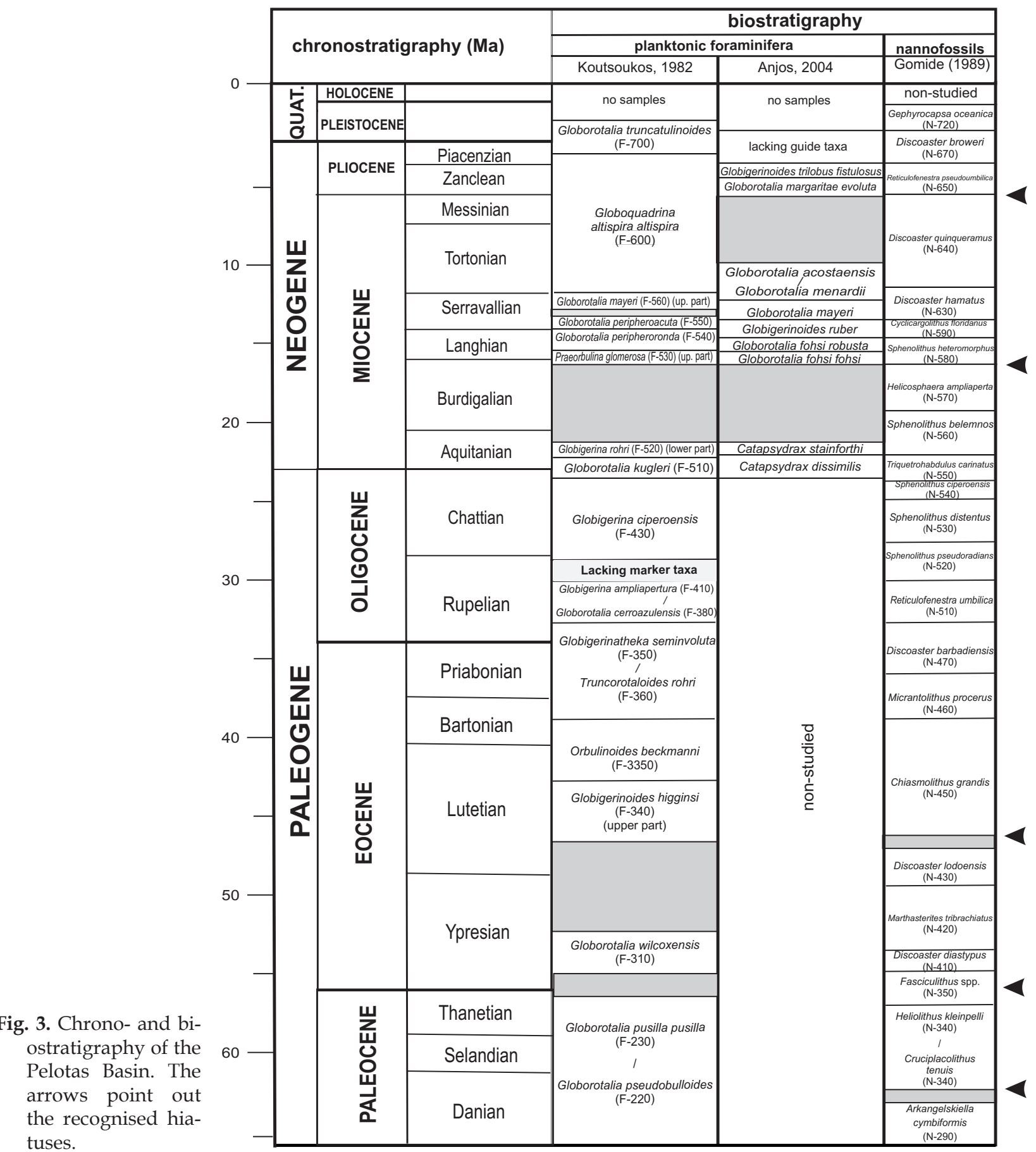


Drill-hole 1A

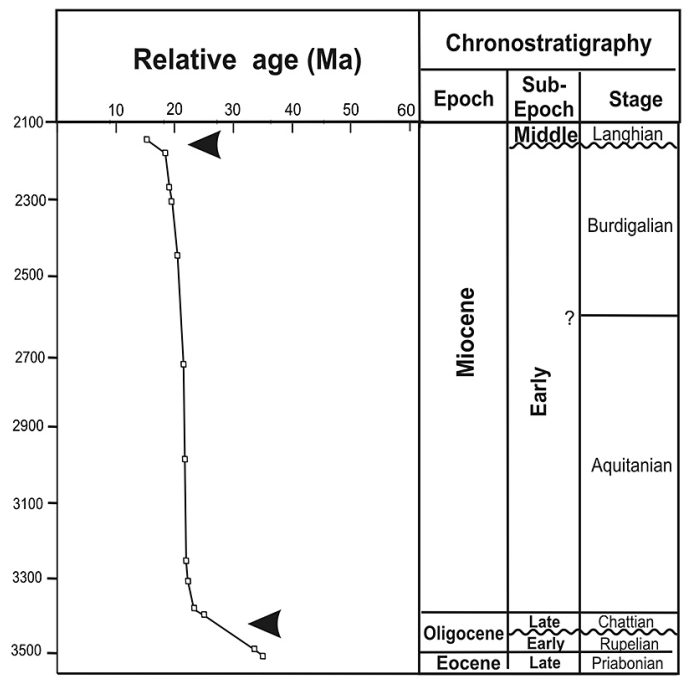

Drill-hole 2-RSS-1

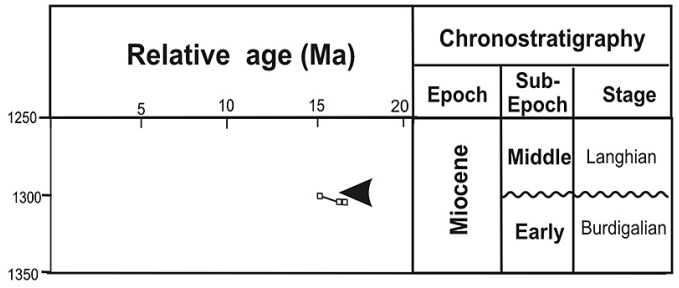

Drill-hole 2A

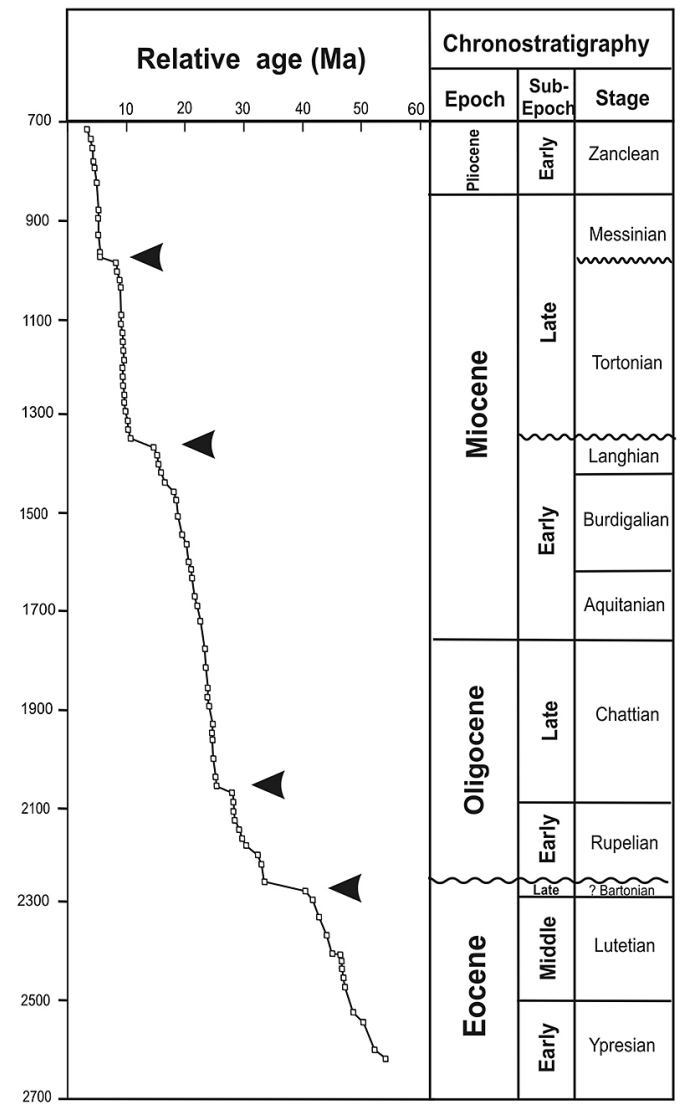

Fig. 4. ${ }^{87} \mathrm{Sr} /{ }^{86} \mathrm{Sr}$ curves of drill-holes 1A, 2A and 2-RSS-1 from the Pelotas Basin [recalculated on the basis of data from McArthur et al., 2001, and McArthur \& Howarth (in Gradstein et al., 2004)]. The shifts in the curve slopes are interpreted as hiatuses (indicated by the arrows).

stratigraphic record above the $\mathrm{K} / \mathrm{Pg}$ boundary (Fig. 3). In the Palaeogene, the DanianSelandian and Thanetian-Ypresian hiatuses were detected by biostratigraphy on the basis of nannofossils (Gomide, 1989) and foraminifers (Koutsoukos, 1982). One important hiatus has been reported from the Eocene (LutetianYpresian), established also with both foraminifer and nannofossil studies. A gentle shift in the ${ }^{87} \mathrm{Sr} /{ }^{86} \mathrm{Sr}$ curve of drill-hole $2 \mathrm{~A}$ may also record this hiatus (Fig. 4). Bueno et al. (2007) also referred to this surface as the middle Eocene unconformity. The ${ }^{87} \mathrm{Sr} /{ }^{86} \mathrm{Sr}$ curve of drill-hole 2A shows a significant shift near the Eocene/Oligocene boundary; the gentler slope of the curve from the latest Eocene to the late Oligocene in the drill-hole $1 \mathrm{~A}$ is evidence of a phase of erosion and/or non-deposition (Fig. 4). Thus, the strontium-isotope data indicate an unconformity embracing the Lutetian-Ru- pelian interval (40--30 Ma) with a time-span of 6.95 Ma. Abreu (1998) identified three sequence boundaries in this interval, based on seismic data; Contreras et al. (2010) also reported an erosional surface and its correlative conformity from this interval on the basis of well logs and seismic data. Another hiatus was identified in drill-hole 2A near the Rupelian/ Chattian boundary (approx. 28 Ma; Fig. 4); its time-span is 2.4 Ma. Contreras et al. (2010; see Fig. 8c) pointed out the discontinuity and interpreted it as a maximum flooding surface.

In the Neogene, two main hiatuses occur. The Aquitanian-Burdigalian hiatus was detected by both Koutsoukos (1982) and Anjos (2004). The ${ }^{87} \mathrm{Sr} /{ }^{86} \mathrm{Sr}$ curves of both drill-holes 1A and 2-RSS-1 display hiatuses at the Burdigalian/Langhian boundary, with a duration of $2.9 \mathrm{Ma}$ and $1.22 \mathrm{Ma}$, respectively (Fig. 4). Drill-hole 2A represents continuous deposi- 
tion throughout the Burdigalian, and a hiatus comprising part of the Langhian and the entire Serravallian, constituting a break in sedimentation of $3.53 \mathrm{Ma}$. Both the biostratigraphical and isotope evidence of the hiatuses is considered here as the record of a strongly diachronous unconformity developed in the early Miocene. Fontana (1996) and Contreras et al. (2010) mentioned an erosional unconformity of early Miocene age; Abreu (1998) identified a sequence boundary close to the Oligocene/ Miocene boundary and three more within the Burdigalian. Another hiatus was assigned to the Tortonian-Messinian by Anjos (2004), but to the Serravallian by Koutsoukos (1982) (Fig. 3). On the basis of the ${ }^{87} \mathrm{Sr} /{ }^{86} \mathrm{Sr}$ curve of drillhole $2 \mathrm{~A}$, a hiatus must be present close to the Tortonian/Messinian boundary, comprising 2.95 Ma (Fig. 4). Fontana (1996) reported the occurrence of an erosional surface at the Serravallian/Tortonian boundary. Abreu (1998) identified one sequence boundary in the uppermost Serravallian and another one in the lowermost Tortonian; the former is related to an important $\delta^{18} \mathrm{O}$ peak. Hiatuses in both the
Lower and Middle-Upper Miocene have been identified by Bueno et al. (2007), who interpreted them as unconformities.

In summary, the following hiatuses were identified in the Cenozoic section of the Pelotas Basin on the basis of the available data: (1) Danian--Thanetian, (2) Thanetian-Ypresian, (3) Ypresian-Lutetian, (4) Lutetian-Rupelian, (5) Rupelian-Chattian, (6) Aquitanian-Burdigalian, and (7) Serravallian-Tortonian (Fig. 3, 4).

\section{Correlation of missing intervals across the SE Brazilian shelf}

The Santos and Campos Basins (Fig. 1) have been well studied due to the numerous exploration projects by the oil industry. Figure 5 shows a simplified chronostratigraphical chart of these basins, based on the revised stratigraphy performed by Moreira et al. (2007) and Winter et al. (2007). The hiatuses shown in Figure 5 are interpreted as unconformities. The following four of these unconformities can be
Fig. 5. Stratigraphy of the Santos and Campos Basins. The arrows point out the unconformities that these basins have in common with the Pelotas Basin. Modified after Moreira et al. (2007) and Winter et al. (2007).
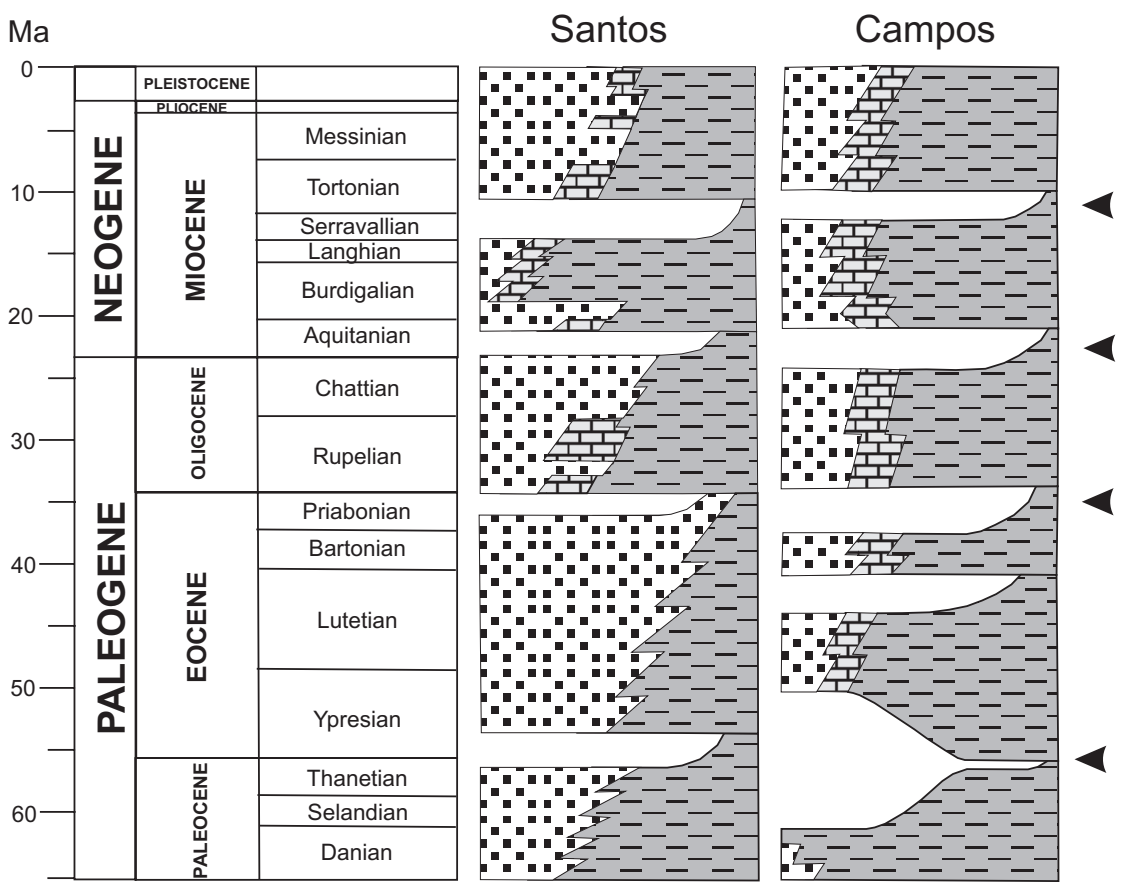

sandstones: fluvial and shallow marine

도돌 limestones: shallow marine

$-\neg$ mudstones: pelagic unconformities in common with Pelotas Basin 
correlated with the hiatuses in the Pelotas Ba$\sin$ (Fig. 5).

(1) A remarkable feature is the strongly diachronous unconformity at approximately the Palaeocene/Eocene boundary. This major unconformity in the Campos Basin corresponds to the entire interval between the Danian-Thanetian and Ypresian-Lutetian unconformities, corresponding to the erosive event ' $\mathrm{A}$ ' of Antunes (1989) that was recorded on the Brazilian continental margin north of the Pelotas Basin.

(2) The unconformity near the Eocene/Oligocene boundary has been identified in the Santos and Campos Basins (Moreira et al., 2007 Winter et al., 2007, Fig. 5). Contreras et al. (2010) considered this surface as a sequence boundary linked to a sea-level fall. According to the presented data and biostratigraphical works (Koutsoukos, 1982; Gomide, 1989; Anjos, 2004), the unconformity embraces the Priabonian and partially the Bartonian, which suggests its strong diachroneity.

(3) The Aquitanian-Burdigalian unconformity was formed, probably, due to an erosive event, considering that Fontana (1996) recognised with seismic profiles and biostratigraphical data an erosional hiatus surface in the lower Miocene succession of the Pelotas Basin, i.e., between 20 and $18 \mathrm{Ma}$. An erosional event of Burdigalian age (approx. 17.4 Ma), called the 'E Event', was registered in the south-eastern part of the Brazilian continental margin (Antunes, 1989; Abreu \& Savini, 1994). Contreras et al. (2010) observed an erosional unconformity at the base of the Miocene in the Campos and Santos Basins; this surface is younger (early Miocene) in the Pelotas Basin.

(4) The Serravallian-Tortonian unconformity has also been recognised in the other basins of the Brazilian continental margin (e.g., Viana et al., 1990; Rossetti, 2001; Arai, 2006; Pasley et al., 2005), representing a regional correlation horizon formed as a consequence of a sea-level fall that peaked in the middle Miocene (Burdigalian-Serravallian). From the Pelotas Basin, Fontana (1996) reported the occurrence of an erosional surface within the upper Miocene succession (approx. $10 \mathrm{Ma}$ ) that would correspond to the Serravallian-Messinian unconformity. An erosional surface of late Miocene age was also reported by Contreras et al. (2010) from the Santos Basin.

\section{Nomenclature of the regional Cenozoic synthems}

The above major unconformities make it possible to establish five synthems on the SE Brazilian shelf, viz. the SEBS-1 (Palaeocene), SEBS-2 (Eocene), SEBS-3 (Oligocene), SEBS-4 (early-middle Miocene) and SEBS-5 (late Miocene to Holocene) (Fig. 6). The synthems are described below and complementary information is presented in Table 1.

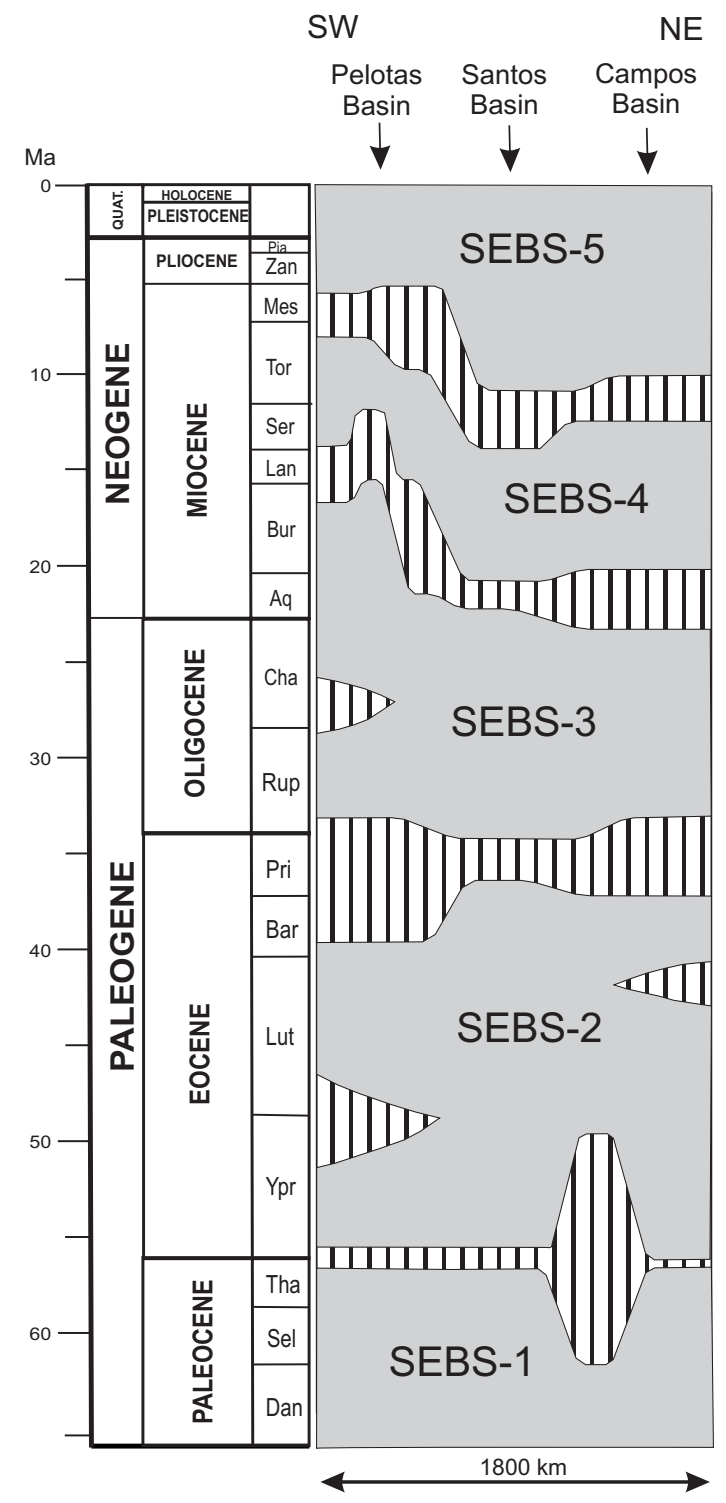

Fig. 6. Proposed synthem stratigraphic framework of the SE Brazilian shelf. 
Table 1. Characteristics of the unconformity-bounded units.

\begin{tabular}{|c|c|c|c|c|}
\hline $\begin{array}{l}\text { syn- } \\
\text { them }\end{array}$ & $\begin{array}{l}\text { time inter- } \\
\text { val }\end{array}$ & $\begin{array}{l}\text { thickness } \\
\text { (m) }\end{array}$ & $\begin{array}{l}\text { lithostratigraphic units } \\
\text { (formations) }\end{array}$ & palaeoenvironments \\
\hline SEBS-5 & $\begin{array}{l}\text { Tortonian - } \\
\text { Holocene }\end{array}$ & $370-700$ & $\begin{array}{l}\text { Cidreira, Imbé, Ponta Aguda, } \\
\text { Iguape, Marambaia, Carapebus, } \\
\text { Emborê (Grussaí and São Tomé } \\
\text { Members), Ubatuba (Geribá } \\
\text { Member) }\end{array}$ & $\begin{array}{l}\text { conglomerates, alluvial fan, fluvial, } \\
\text { sandstones, diamicti- coastal, shelf, submarine } \\
\text { tes, peats, mudstones channel-lobe complex }\end{array}$ \\
\hline SEBS-4 & $\begin{array}{l}\text { Aquitani- } \\
\text { an/Bur- } \\
\text { digalian - } \\
\text { Tortonian }\end{array}$ & $370-650$ & $\begin{array}{l}\text { Cidreira, Imbé, Barreiras, Ponta } \\
\text { Aguda, Iguape, Marambaia, Em- } \\
\text { borê (São Tomé and Siri Mem- } \\
\text { bers), Ubatuba (Geribá Member), } \\
\text { Carapebus }\end{array}$ & $\begin{array}{l}\text { conglomerates, sand- alluvial fan, fluvial, } \\
\text { stones, mudstones, coastal, shelf, submarine } \\
\text { reefal and bioclastic channel-lobe complex } \\
\text { carbonates }\end{array}$ \\
\hline SEBS-3 & $\begin{array}{l}\text { Priabonian } \\
\text { - Aquitani- } \\
\text { an/Burdi- } \\
\text { galian }\end{array}$ & $350-1,300$ & $\begin{array}{l}\text { Cidreira, Imbé, Ponta Aguda, } \\
\text { Iguape, Marambaia (Maresias } \\
\text { Member), Emborê (São Tomé } \\
\text { and Grussaí Members), Ubatuba } \\
\text { (Geribá Member), Carapebus }\end{array}$ & $\begin{array}{ll}\text { sandstones, mudsto- } & \text { coastal, shelf, submarine } \\
\text { nes, carbonates } & \text { channel-lobe complex }\end{array}$ \\
\hline SEBS-2 & $\begin{array}{l}\text { Ypresian - } \\
\text { Late Barto- } \\
\text { nian/ } \\
\text { Early Pria- } \\
\text { bonian }\end{array}$ & $270-1,300$ & $\begin{array}{l}\text { Imbé, Ponta Aguda, Marambaia, } \\
\text { Carapebus, Emborê (Grussaí and } \\
\text { São Tomé Members) }\end{array}$ & $\begin{array}{l}\text { sandstones, conglo- coastal, shelf, submarine } \\
\text { merates, diamictites, channel-lobe complex } \\
\text { mudstones, carbo- } \\
\text { nates, marls, basaltic } \\
\text { flows, peperites }\end{array}$ \\
\hline SEBS-1 & $\begin{array}{l}\text { Danian - } \\
\text { Ypresian }\end{array}$ & $200-600$ & $\begin{array}{l}\text { Cidreira, Imbé, Ponta Aguda, Ma- } \\
\text { rambaia, Carapebus, Emborê (São } \\
\text { Tomé Member), Ubatuba (Geribá } \\
\text { Member) }\end{array}$ & $\begin{array}{ll}\text { sandstones, conglo- } & \text { alluvial fan, fluvial, } \\
\text { merates, diamictites, } & \text { coastal, shelf, submarine } \\
\text { mudstones, marls } & \text { channel-lobe complex }\end{array}$ \\
\hline
\end{tabular}

\subsection{Synthem SEBS-1}

This synthem comprises an interval between the Cretaceous/Tertiary boundary and the uppermost Thanetian (Pelotas Basin) to the uppermost Ypresian (Campos Basin). It is composed (from base to top) by the planktonic foraminifer-based zones Globorotalia pseudobulloides (currently Parasubbotina pseudobulloides) and Globorotalia pusilla pusilla (currently Igorina pusilla) (Koutsoukos, 1982) and the nannofossil-based zones N-290 (Arkangelskiella cymbiformis), N-340 (Heliolithus kleinpelli) and N-350 (Fasciculithus spp.) (Gomide, 1989).

The hiatus between the zones N-290 and N-340 is considered to be a local feature representing either erosion or non-deposition in the Pelotas Basin, as it has no continuity to the other basins (Figs. 3, 6).

\subsection{Synthem SEBS-2}

This synthem rests on the Palaeocene-Eocene unconformity, and it encompasses a strati- graphic interval from the lowermost Ypresian to the upper Bartonian-lower Priabonian.

According to the data published by Koutsoukos (1982) for the Pelotas Basin, the SEBS-2 synthem comprises the foraminifer-based zones Globorotalia wilcoxensis (currently Acarinina wilcoxensis), Globigerinoides higginsi (currently Gumbelitrioides nuttalli) (upper part), Orbulinoides beckmanni, and Globigerinatheka semiinvoluta / Truncorotaloides rohri (currently Acarinina rohri). This unit encompasses the nannofossil-based zones N-410 (Discoaster diastypus), N-420 (Marthasterites tribrachiatus), N-430 (Discoaster lodoensis), N-450 (Chismolithus grandis), N-460 (Micrantolithus procerus) and N-470 (Discoaster barbadiensis) according to Gomide (1989). The absence of the zones Globorotalia pseudomenardii (currently Globanomalina pseudomenardii) and Globorotalia velascoensis (currently Morozovella velascoensis) between the Globorotalia wilcoxensis (currently Morozovella wilcoxensis) and the upper part of the Globigerinoides higginsi zones and the zone N-440 (Chiasmolithus gigas) is interpreted as a regional hiatus (Figs 3, 6). 
Volcanic rocks are related to the Abrolhos Magmatic Event ( $53 \pm 2 \mathrm{Ma}$ ) and the Middle Eocene Magmatic Event.

\subsection{Synthem SEBS-3}

This synthem was deposited on top of the upper Eocene-lowermost Oligocene unconformity, ranging from the lowermost Rupelian to the upper Burdigalian (in the Pelotas Basin) or the lower Aquitanian (in the Santos and Campos Basins). In the Pelotas Basin, SEBS-3 encompasses the foraminifer-based zones Globigerina ampliapertura (currently Turborotalia ampliapertura) / Globorotalia cerroazulensis (currently Turborotalia cerrozulensis), Globigerina ciperoensis, Globorotalia kugleri (currently Paragloborotalia kugleri), and the lower part of the Globigerina rohri (currently Globoquadrina rohri) (Koutsoukos, 1982). According to Anjos (2004), the upper part of this synthem is also related to the planktonic foraminifer-based zones Catapsydrax dissimilis and Catapsydrax stainforthi.

The nannofossil-based zones N-510 (Reticulofenestra umbilica), N-520 (Sphenolithus pseudoradians), N-530 (Sphenolithus distentus), N-540 (Sphenolithus ciperoensis), N-550 (Triquetrohabdulus carinatus), and the lower part of N-560 (Sphenolithus belemnos) (Gomide, 1989) can also be correlated with the interval of SEBS-3.

A carbonate mudstone horizon bearing nannoplankton (Braarudosphaera bigelowi) has been reported from the Campos Basin; this level is an important stratigraphic marker (the so-called 'Blue Mark') interpreted as a flooding surface (Shimabukuro, 1994).

\subsection{Synthem SEBS-4}

This unit, which overlies the strongly diachronous lower-middle Miocene unconformity, comprises the Burdigalian-Serravallian interval in the Campos and Santos Basins, and it is younger in the Pelotas Basin, where it ranges from the late Langhian to the late Tortonian. Following the scheme of Koutsoukos (1982), this synthem comprises the planktonic foraminifer-based zones Preaeorbulina glomerosa (upper part), Globorotalia fohsi peripheroronda, Globorotalia fohsi peripheroacuta, Globorotalia mayeri (currently Paragloborotalia mayeri) (upper part), and part of Globoquadrina altispira altispira. As for the biozonation proposed by Anjos (2004), the synthem embraces the international foraminifer zones of Bolli \& Saunders (1985), viz. the Globorotalia fohsi fohsi, Globorotalia fohsi robusta, Globigeronoides ruber, Globorotalia mayeri, and Globorotalia menardii / Globorotalia acostaensis zones.

SEBS-4 includes the nannofossil-based zones N-580 (Sphenolithus heteromorphus), N-540 (Sphenolithus ciperoensis), N-630 (Discoaster hamatus) and N-640 (Discoaster quinqueramus) (Gomide, 1989).

\subsection{Synthem SEBS-5}

Deposition of this synthem took place during the earliest Tortonian in the northern part of the shelf (Campos and Santos Basins). In the Pelotas Basin, it began later, in the Messinian. The sedimentary succession comprises the entire interval up to the Holocene. Previous biostratigraphical works (Koutsoukos, 1982; Gomide, 1989; Anjos, 2004) do not deal with this interval, and the Quaternary biozones are not characterised.

In terms of planktonic foraminifers, the upper part of the Globoquadrina altispira altispira and Globorotalia truncatulinoides zones suggested by Koutsoukos (1982) comprise the upper Miocene-Pliocene interval; Anjos (2004) recognised the zones Globorotalia margaritae evoluta and Globigerinoides trilobus fistulosus at the Miocene/Pliocene transition.

The nannofossil-based zones N-650 (Reticulofenestra pseudoumbilica), N-670 (Discoaster broweri) and N-720 (Gephyrocapsa oceanica) were identified by Gomide (1989); they comprise the interval between the upper Miocene and the Pleistocene.

\section{Discussion}

The Cenozoic unconformities established on the SE Brazilian shelf, i.e., those that the 
Pelotas, Santos, and Campos Basins have in common, can be correlated with the major unconformities established in other large regions of the globe with a relatively stable tectonic regime. For the purposes of the present study, the regions with recently established stratigraphic frameworks are considered (these regions are presented in Fig. 7, together with the sources of the relevant stratigraphical data). Only those unconformities which are traced over a signifi- cant part of each of these regions are judged to be major. The analysis is limited to the 65-10 Ma time interval, i.e., middle Danian-early Tortonian, in order to avoid difficulties linked to the recognition of multiple unconformities related to frequent lowstands during the late Cenozoic icehouse conditions.

Correlation of the Cenozoic regional records shows two common sedimentation breaks (Fig. 7). The first marks the Eocene/

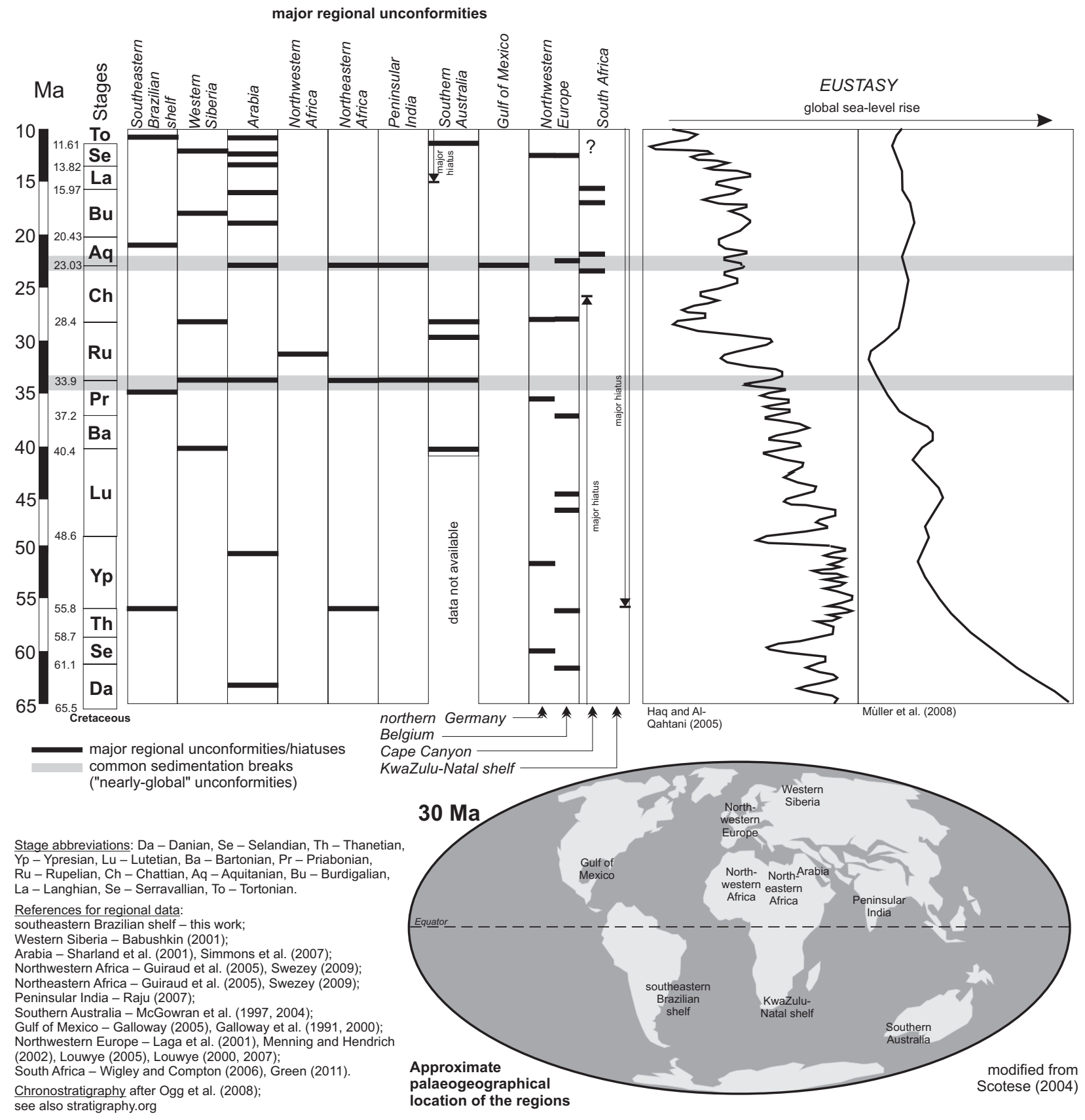

Fig. 7. Inter-regional correlation of the major regional unconformities, common sedimentation breaks, and eustatic fluctuations during the 65-10 Ma time-span. 
Oligocene boundary. It is expressed by major unconformities in some two thirds of the regions under consideration. This sedimentation break coincides with the global sea-level fall of Haq \& Al-Qahtani (2005), who updated the earlier reconstructions by Haq et al. (1987), and Kominz et al. (2008), who updated the earlier reconstructions by Miller et al. (2005). The more generalised eustatic curve reconstructed by Müller et al. (2008), which accounts for global tectonic mechanisms of sea-level changes, shows a significant lowstand in the Rupelian (Fig. 7), and it cannot be excluded that this event was related to the sedimentation break at the Eocene/Oligocene boundary. It appears that this common sedimentation break resulted from the Oi-1 glaciation at this boundary (Abreu \& Anderson, 1998; Zachos et al., 2001; Gornitz, 2009; Zalasiewicz \& Williams, 2012) that caused the major global eustatic fall. The second common sedimentation break occurred at the Oligocene/Miocene boundary, and also left a signature in the majority of the regions under consideration. Although it coincided with a less strong eustatic fall as depicted by Haq \& Al-Qahtani (2005), this break corresponded to a recognisable global sea-level fall, as reconstructed by both Kominz et al. (2008) and Müller et al. (2008) (Figs 7, 8). Most probably, this common sedimentation break resulted from the major glaciation (Mi-1) that took place at the Oligocene/Miocene transition (Abreu \& Anderson, 1998; Zachos et al., 2001; Gornitz, 2009; Zalasiewicz \& Williams, 2012).

From the four Cenozoic unconformities established on the SE Brazilian shelf as synthem boundaries (Fig. 6), the only one that corresponds well to one of the above-mentioned 'nearly-global' unconformities and permits to postulate a global eustatic nature is the one at the Eocene/Oligocene boundary (Fig. 7). The other synthem boundaries established in the Pelotas, Santos, and Campos Basins can, however, have the same origin. Figure 8 shows the position of these unconformities in relation to eustatic (Haq \& Al Qahtani, 2005; Kominz et al., 2008; Miller et al., 2008), $\delta^{18} \mathrm{O}$ (Miller et al., 2008; Zachos et al., 2008), and $\delta^{13} C$ (Kurz et al., 2003) records. Except for the Danian-Thanetian unconformity, which could correspond to a fall that is present only on the Miller et al. (2008) curve, all unconformities correspond to eustatic falls that are indicated on the various sea-level curves (also taking into account an error margin in relation to the data used here and between the curves themselves). Ruban et al. $(2010,2012)$ also noted the possibility of a strong nearly-global regression in the second half of the Thanetian, which may explain the Danian-Thanetian unconformity.

This evidence does, obviously, not imply that the regional tectonic activity did not affect the synthem stratigraphic architecture. Differences between the basins with regard to the quantity and stratigraphical position of hiatuses (Fig. 6) may be explained as results of such an activity, e.g., local uplifts in the Pelotas Basin may explain the origin of those surfaces that have no analogues in the Santos and Campos Basins.

It is interesting to put the unconformities of the SE Brazilian shelf into the wider context. The Palaeocene/Eocene (Thanetian/Ypresian) boundary is present as a distinctive surface in W Europe (e.g., top of the Thanet Formation, London Basin; base of Ieper Formation, Belgium; Walsh, 2004). A negative carbon-isotope excursion characterises this interval (Fig. 8) for both marine and continental realms; it coincides with a benthic-foraminifer extinction event (Koch et al., 1992; Berggren \& Aubry, 1996; Schmitz et al., 1998; Walsh, 2004).

In addition, warming is indicated by oxygen-isotope data (Berggren \& Aubry, 1996), which event is known as the Palaeocene-Eocene Thermal Maximum (PETM) (Zachos et al., 2008; Fig. 8). A global sea-level fall is thought to be primarily related with the unconformities in the marginal basins of NW Europe, and lowstand deep-water deposits are their equivalents in the North Sea Basin (Berggren \& Aubry, 1996). Glacio-eustatic mechanisms seem to be irrelevant under the early Cenozoic greenhouse conditions (e.g., Zachos et al., 2001; Gornitz, 2009; Zalasiewicz \& Williams, 2012), and tectonically driven processes such as the balance between production and consumption of oceanic crust must be considered.

The release of $\mathrm{CO}_{2}$ accumulated in the sediment to the ocean-atmosphere system is also 


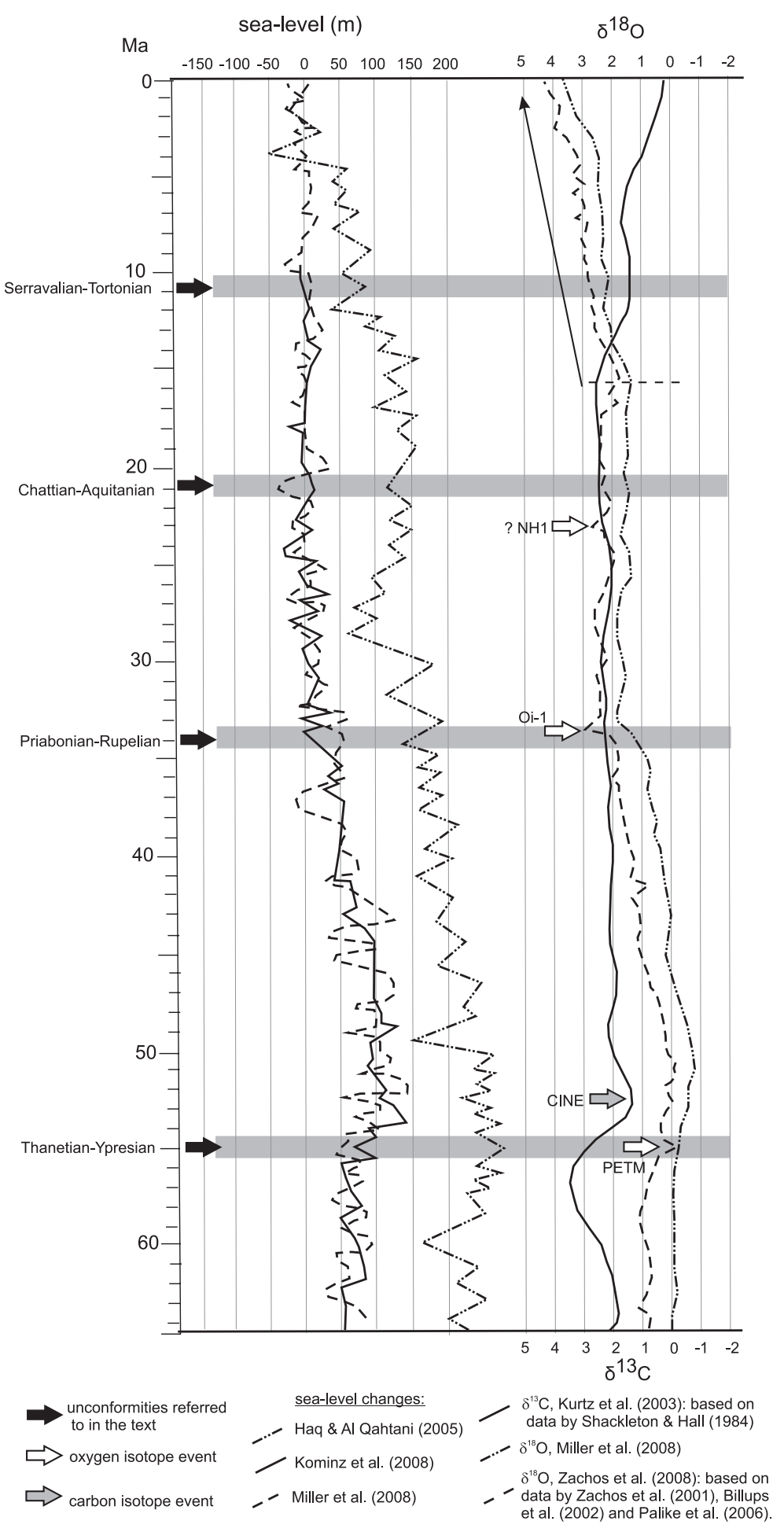

Fig. 8. Global Cenozoic sea-level, $\delta^{13} \mathrm{C}$, and $\delta^{18} \mathrm{O}$ curves. The events indicated are referred to in the text. Abbreviations: CINE $=$ carbon-isotope negative excursion, $\mathrm{PETM}=$ Paleocene-Eocene Thermal Maximum.

sea-level fall and the climate in an ice-free pe-

a matter of debate. It has been hypothesised that the accumulated carbon is of continental origin, but is may also have a marine origin (Kurz et al., 2003; Zachos et al., 2008). Moreover, the PETM that can be deduced from the $\delta^{18} \mathrm{O}$ suggests a phase of important environmental changes. The causal relationship between the riod, though, is uncertain. Interestingly, Ruban et al. (2012) provided evidence for the absence of coherent shoreline shifts under the early Cenozoic greenhouse conditions.

The Eocene-Oligocene unconformity corresponds to a fall in the sea level, as expressed in 
sea-level curves, especially that by Haq \& Al Qahtani (2005; Fig. 8). The sea-level fall at 33.5 Ma marks an important pulse in the development of the ice cap in Antarctica and the beginning of the long-term icehouse conditions that last until the present day; a related event is the positive excursion in $\delta^{18} \mathrm{O}(\mathrm{Oi}-1, \mathrm{Fig} .8)$, marking a planetary-scale deep-water cooling (Miller et al., 2008).

The early Miocene (Aquitanian-Burdigalian) unconformity corresponds to a glacio-eustatic sea-level fall and a major cooling, defined by Keller \& Barron (1983) as NH1. A positive excursion in the $\delta^{18} \mathrm{O}$ curves by both Miller et al. (2008) and Zachos et al. (2008) (Fig. 8) is here supposed to be related to this event. Furthermore, others (Vail \& Hardenbol, 1979; Haq et al.; 1988) have referred to a eustatic fall at this time. In fact, a well-marked fall is present in the sea-level curves, principally that constructed by Miller et al. (2008).

The middle-late Miocene (Serravallian-Tortonian) unconformity is also related to a major cooling event. After the late-middle Miocene climatic optimum, a phase of gradual cooling started; it was related to the re-establishment of the Antarctic ice sheet (Zachos et al., 2001). Miller et al. (1987) inferred an event of ice-sheet growth by $10 \mathrm{Ma}$ and the sea-level curves by both Haq and Al Qahtani (2005) and Miller et al. (2008) show falls close to this interval, despite some variation between the two curves with respect to the age (Fig. 8). Additionally, faunal and $\delta^{18} \mathrm{O}$ data indicate a cooling and an increase in the global ice-sheet volume by 14.8 to $10 \mathrm{Ma}$ (Shackleton \& Kennett, 1975; Hodell \& Kennett, 1985; Miller et al., 2008). This is shown in the $\delta^{18} \mathrm{O}$ curves as an inflection of the increasing trend that lasts until the Holocene (Fig. 8).

\section{Conclusions}

Lithological, biostratigraphical, and isotope data allow the recognition of important unconformities which separate synthems on the SE Brazilian shelf that are traceable regionally or even globally. The five most important region- al and interregional conclusions are presented below.

(1) Seven surfaces representing hiatuses have been identified in the Pelotas Basin; they represent (a) Palaeocene (Danian-Thanetian), (b) Palaeocene-Eocene (Thanetian-Ypresian) (c) Eocene (Ypresian-Lutetian), (d) EoceneOligocene (Lutetian-Rupelian), (e) Oligocene (Rupelian-Chattian), (f) early Miocene (Aquitanian-Burdigalian) and (g) middle-late Miocene (Serravallian-Messinian) time-spans.

(2) Regional correlation of these surfaces over the SE Brazilian shelf makes it possible to recognise four important unconformities, which occur (a) at the Paleocene/Eocene and (b) Eocene/Oligocene transitions, (c) in the lower Miocene (Aquitanian-Burdigalian), and (d) in the middle-late Miocene (SerravallianTortonian).

(3) The synthems based on these surfaces have been defined as SEBS-1 (Palaeocene), SEBS-2 (Eocene), SEBS-3 (Oligocene), SEBS-4 (early-middle Miocene) and SEBS-5 (late Miocene-Holocene).

(4) From the regional unconformities, the only one that coincides with a nearly-global sedimentation break outlined by the interregional correlation of unconformities is positioned near the Eocene/Oligocene boundary.

(5) All regional unconformities (with a possible exception of that at the Palaeocene/Eocene boundary) and synthems were presumably formed due to significant global eustatic sea-level fluctuations.

The present contribution focuses on the only probable (glacio-)eustatic origin of the Cenozoic synthems and unconformities established on the SE Brazilian shelf. Regional tectonic activity and changes in sediment delivery to the shelf should, however, also be considered. It is, for instance, possible that they may explain the diachroneity of the hiatuses (Fig. 6). The controlling factors of the regional synthem stratigraphical architecture consequently deserve further investigation.

\section{Acknowledgements}

The authors gratefully thank Petrobras (Petróleo Brasileiro S.A.) for supplying the samples, the Pro- 
ject FINEP-CTPETRO (Project No. 6500.0026.00) for financial support for analyses of the samples, and the Brazilian National Petroleum Agency (ANP) for funding the studies of G.S.A.Z. Our special thanks are addressed to J.M. McArthur (U.K.) for providing a strontium-ratios look-up table and also to C.P. Conrad (U.S.A.), W. Riegraf (Germany), N. Vandenberghe (Belgium), V.S. Volkova (Russia), and some other colleagues for their advices and/or generous help with literature.

\section{References}

Abreu, V.S., 1998. Geologic evolution of conjugate volcanic passive margins: Pelotas Basin (Brazil) and offshore $\mathrm{Na}$ mibia (Africa): implication for global sea-level changes. Ph.D. thesis, Rice University.

Abreu, V.S. \& Anderson, J.B., 1998. Glacial eustasy during the Cenozoic: sequence stratigraphic implications. American Association of Petroleum Geologists Bulletin 82, 1385-1400.

Abreu, V.S. \& Savini, R.R., 1994. Major paleoceanographic events of the Brazilian continental margin: relationships with the giant oil fields of the Oligo-Miocene of Campo Basin, Brazil. 26 $6^{\text {th }}$ Annual Offshore Technology Conference (Houston, Texas, 1994), 335-344.

Anjos, G.S., 2004. Bioestratigrafia (Foraminiferida) do Mioceno-Plioceno da Plataforma de Florianópolis, porção setentrional da Bacia de Pelotas. [Biostratigraphy (Foraminiferida) of the Miocene-Pliocene of the Florianópolis Platform, northern part of the Pelotas Basin]. M.Sc. Thesis, Universidade Federal do Rio Grande do Sul.

Anjos, G.S. \& Carreño, A. L., 2004. Bioestratigrafia (Foraminiferida) da sondagem 1-SCS-3B, Plataforma de Florianópolis, Bacia de Pelotas. [Biostratigraphy (Foraminiferida) of the drilling 1-SCS-3B, Florianópolis Platform, Pelotas Basin]. Revista Brasileira de Paleontologia 7, 127-138.

Anjos-Zerfass, G.S., 2009. Estudos paleoambientais com base em isótopos de carbono, oxigênio e estrôncio em foraminíferos do Terciário da Bacia de Pelotas. [Palaeoenvironmental study based on carbon, oxygen and strontium isotopes in foraminifers from the Tertiary of the Pelotas Basin]. Ph.D. Thesis, Universidade Federal do Rio Grande do Sul.

Antunes, R.L., 1989. Cenozoic erosive events in central-northern portion of the Santos Basin-Brazil: a biochronoestratigraphical study based on calcareous nannofossils. Anais do XXI Congresso Brasileiro de Paleontologia, 1043-1058.

Arai, M., 2006. A grande elevação eustática do Mioceno e sua influência na origem do Grupo Barreiras. [The large eustatic rise of the Miocene and its influence on the origin of the Barreiras Group]. Revista do Instituto de Geociências-USP 6, 1-6.

Asmus, H.E. \& Baisch, P.R., 1983. Geological evolution of the Brazilian continental margin. Episodes 6, 3-9.

Babushkin, A.E. (Ed.), 2001. Unifitsirovannye regional'nye stratigrafitcheskie skhemy neogenovykh i paleogeonovykh otlozhenij Zapadno-Sibirskoj ravniny. [Unified regional stratigraphic scales of Neogene and Paleogene deposits of the West Siberian plain]. SNIIGGiMS, Novosibirsk, 84 pp.

Bassetto, M., Alkmim, F., Szatmari, P., Mohriak, W.U., 2000. The oceanic segment of the southern Brazilian margin: morpho-structural domains and their tectonic significance. [In:] W.U. Mohriak \& M. Talwani (Eds): Atlantic rifts and continental margins. American Geophysical Union, Monograph 115, 235-259.

Berggren, W.A. \& Aubry, M.-P., 1996. A late Paleocene-early Eocene NW European and North Sea magnetobiochronological correlation network. [In:] R.W.O.B. Knox, R.M. Corfield \& R.E. Dunay (Eds): Correlation of the Early Paleogene in Northwestern Europe. Geological Society of London Special Publication 101, 309-352.

Billups, K., Channell, J.E.T. \& Zachos, J., 2002. Late Oligocene to early Miocene geochronology and paleoceanography from the subantarctic South Atlantic. Paleoceanography U39-U49.

Bolli, H.M. \& Saunders, J.B., 1985. Oligocene to Holocene low latitude planktic foraminifera. [In:] H.M. Bolli, J.B. Saunders \& K. Perch-Nielsen (Eds): Plankton stratigraphy. Cambridge University Press, Cambridge, 155-262.

Bueno, G.V., Zacharias, A.A., Oeiro, S.G., Cupertino, J.A., Falkenhein, F.U.H. \& Martins Neto, M.A., 2007. Bacia de Pelotas. [Pelotas Basin]. Boletim de Geociências da Petrobras 15, 551-559.

Burke, W.H., Denison, R.E., Hetherington, E.A., Koepnick, R.B., Nelson, H.F. \& Otto, J.B., 1982. Variation of seawater ${ }^{87} \mathrm{Sr} /{ }^{86} \mathrm{Sr}$ through Phanerozoic time. Geology 10, 516-519.

Cainelli, C. \& Mohriak, W.U., 1999. Some remarks on the evolution of sedimentary basins along the eastern Brazilian continental margin. Episodes 22, 206-216.

Catuneanu, O., 2006. Principles of sequence stratigraphy. Elsevier, Amsterdam, $375 \mathrm{pp}$.

Catuneanu, O., Abreu, V., Bhattacharya, J.P., Blum, M.D., Dalrymple, R.W., Eriksson, P.G., Fielding, C.R., Fisher, W.L., Galloway, W.E., Gibling, M.R., Giles, K.A., Holbrook, J.M., Jordan, R., Kendall, C.G.St.C., Macurda, B., Martinsen, O.J., Miall, A.D., Neal, J.E., Nummedal, D., Pomar, L., Posamentier, H.W., Pratt, B.R., Sarg, J.F., Shanley, K.W., Steel, R.J., Strasser, A., Tucker, M.E. \& Winker, C., 2009. Towards the standardization of sequence stratigraphy. Earth-Science Reviews 92, 1-33.

Catuneanu, O., Bhattacharya, J.P., Blum, M.D., Dalrymple, R.W., Eriksson, P.G., Fielding, C.R., Fisher, W.L., Galloway, W.E., Gibling, M.R., Giles, K.A., Holbrook, J.M., Jordan, R., Kendall, C.G.St.C., Macurda, B., Martinsen, O.J., Miall, A.D., Nummedal, D., Posamentier, H.W., Pratt, B.R., Shanley, K.W., Steel, R.J., Strasser, A. \& Tucker, M.E., 2010. Sequence stratigraphy: common ground after three decades of development. First Break 28, 21-34.

Catuneanu, O., Galloway, W.E., Kendall, C.G.St.C., Miall, A.D., Posamentier, H.W., Strasser, A. \& Tucker, 
M.E., 2011. Sequence stratigraphy: methodology and nomenclature. Newsletters on Stratigraphy 44, 173-245.

Chang, K.H., 1975. Unconformity-bounded stratigraphic units. Geological Society of America Bulletin 86, 15441552.

Chang, H.K., Kowsmann, R.O., Figueiredo, A.M.F. \& Bender, A.A., 1992. Tectonics and stratigraphy of the East Brazil Rift System: An overview. Tectonophysics 213, 97-138.

Conceição, J.C.J., Zalán, P.V. \& Wolff, S., 1988. Mecanismo, evolução e cronologia do rift Sul-Atlântico. [Mechanism, evolution and chronology of the South Atlantic rift]. Boletim de Geociências da Petrobras 2, 255265.

Contreras, J., Zühlke, R., Bowman, S. \& Bechstädt, T., 2010. Seismic stratigraphy and subsidence analysis of the southern Brazilian margin (Campos, Santos and Pelotas basins). Marine and Petroleum Geology 27, 1952-1980.

Dias, J.L., 2009. Estratigrafia e sedimentação dos evaporitos neo-aptianos na Margem Leste Brasileira. [Stratigraphy and sedimentation of Late Aptian evaporites in the Brazilian eastern margin]. [In:] W. Mohriak, P., Szatmari, P., Anjos, S.M.C. (Eds): Sal: Geologia e Tectônica. [Salt: Geology and Tectonics]. Petrobras, Beca, São Paulo, 222-231.

Elderfield, H., 1986. Strontium isotope stratigraphy. Palaeogeography, Palaeoclimatology, Palaeoecology 57, 71-90.

Fontana, R.L., 1996. Geotectônica e sismoestratigrafia da Bacia de Pelotas e Plataforma de Florianópolis. [Geotectonics and seismostratigraphy of the Pelotas Basin and Florianópolis Platform]. Ph.D. Thesis, Universidade Federal do Rio Grande do Sul.

Galloway, W.E., 2005. Gulf of Mexico Basin depositional record of Cenozoic North American drainage basin evolution. International Association of Sedimentologists Special Publication 35, 409-423.

Galloway, W.E., Bebout, D.G., Fisher, W.L., Dunlap, J.B., Jr., Cabrera-Castro, R., Lugo-Rivera, J.E. \& Scott, T.M., 1991. Cenozoic. [In:] A. Salvador (Ed.): The geology of North America. Vol. J. The Gulf of Mexico Basin. Geological Society of America, Boulder, 245-324.

Galloway, W.E., Ganey-Curry, P.E., Li, X. \& Buffler, R.T., 2000. Cenozoic depositional history of the Gulf of Mexico basin. American Association of Petroleum Geologists Bulletin 84, 1743-1774.

Gomide, J., 1989. Bacia de Pelotas - Biocronoestratigrafia baseada em nanofósseis calcários. [Pelotas Basin - Biochronostratigraphy based on calcareous nannofossils]. Congresso Brasileiro de Paleontologia, Anais 11, 338-351.

Gornitz, V. (Ed.), 2009. Encyclopedia of paleoclimatology and ancient environments. Springer, Dordrecht, $1049 \mathrm{pp}$.

Gradstein, F.M., Ogg, J.G., Smith, A.G., Agterberg, F.P., Bleeker, W., Cooper, R.A., Davydov, V., Gibbard, P., Hinnov, L.A., House, M.R., Lourens, L., Luterbacher, H.P., McArthur, J., Melchin, M.J., Robb, L.J., Shergold, J., Villeneuve, M., Wardlaw, B.R., Ali, J., Brinkhuis, H., Hilgen, F.J., Hooker, J., Howarth, R.J., Knoll, A.H., Laskar, J., Monechi, S., Plumb, K.A., Powell, J., Raffi, I., Rohl, U., Sadler, P., Sanfilippo, A., Schmitz, B.,
Shackleton, N.J., Shields, G.A., Strauss, H., Van Dam, J., Van Kolfschoten, T., Veizer, J. \& Wilson, D., 2004. A geologic time scale 2004. Cambridge University Press, Cambridge, $589 \mathrm{pp}$.

Green, A., 2011. The late Cretaceous to Holocene sequence stratigraphy of a sheared passive upper continental margin, northern KwaZulu-Natal, South Africa. Marine Geology 289, 17-28.

Guiraud, R., Bosworth, W., Thierry, J. \& Delplanque, A., 2005. Phanerozoic geological evolution of Northern and Central Africa: An overview. Journal of African Earth Sciences 43, 83-143.

Haq, B.U., Hardenbol, J. \& Vail, P.R., 1987. Chronology of fluctuating sea levels since the Triassic. Science 235, 1156-1167.

Haq, B.U., Hardenbol, J. \& Vail, P.R. 1988. Mesozoic and Cenozoic chronostratigraphy and cycles of sea-level change. Society of Economic Paleontologists and Mineralogists Special Publication 42, 71-108.

Haq, B.U. \& Al-Qahtani, A.M., 2005. Phanerozoic cycles of sea-level change on the Arabian Platform. GeoArabia $10,127-160$.

Hess, J., Bender, M.L. \& Schilling, J. 1986. Evolution of the ratio of strontium 87 to strontium 86 in seawater from Cretaceous to Present. Science 231, 979-984.

Hodell, D.A. \& Kennett, J.P., 1985. Miocene paleoceanography of the South Atlantic Ocean at 22, 16 and $8 \mathrm{Ma}$. [In:] J.P. Kennett (Ed.): The Miocene ocean: paleoceanography and biogeography. Geological Society of America Memoir 163, 317-337.

Hodell, D.A., Mueller, P.A. \& Garrido, J.R., 1991. Variation in the strontium isotope composition of the seawater during the Neogene. Geology 19, 24-27.

Hodell, D.A. \& Woodruff, F., 1994. Variations in the strontium isotopic ratio of seawater during the Miocene: Stratigraphic and geochemical implications. Paleoceanography 9, 405-426.

Ielpi, A., 2012. Orbitally-driven climate forcing in late Pliocene lacustrine siderite-rich clastic rhythms (Upper Valdarno Basin, Northern Apennines, Italy). Palaeogeography, Palaeoclimatology, Palaeoecology 331-332, 119-135.

Keller, G. \& Barron, J.A., 1983. Paleoceanographic implications of Miocene deep-sea hiatuses. Geological Society of America Bulletin 94, 590-613.

Koch, P.L., Zachos, J.C. \& Gingerich, P.D., 1992. Correlation between isotope records in marine and continental carbon reservoirs near the Palaeocene/Eocene boundary. Nature 358, 319-322.

Kominz, M.A., Browning, J.V., Miller, K.G., Sugarman, P.J., Mizintseva, S. \& Scotese, C.R., 2008. Late Cretaceous to Miocene sea-level estimates from the New Jersey and Delaware coastal plain boreholes: an error analysis. Basin Research 20, 211-226.

Koutsoukos E.A.M., 1982. Geohistória e paleoecologia das bacias marginais de Florianópolis e Santos. [Geohistory and palaeoecology of the Florianópolis and Santos marginal basins]. Congresso Brasileiro de Geologia, Anais 32, 2369-2382.

Kowsmann, R.O., Francisconi, O. \& Leyden, R., 1974. Refração sísmica marinha nas bacias de Pelotas, Santos 
Sul e na Plataforma de Torres. [Marine seismic refraction in the Pelotas and Southern Santos basins and Torres Platform]. Congresso Brasileiro de Geologia, Anais 28, 283-295.

Kurz, A.C., Kump, L.R., Arthur, M.A., Zachos, J.C. \& Paytan, A., 2003. Early Cenozoic decoupling of the global carbon and sulphur cycles. Paleoceanography 18, DOI: 10.1029/2003PA000908.

Laga, P., Louwye, S. \& Geets, S., 2001. Paleogene and Neogene lithostratigrafie units (Belgium). Geologica Belgica 4, 135-152.

Louwye, S., 2005. The Early and Middle Miocene transgression at the southern border of the North Sea Basin (northern Belgium). Geological Journal 40, 441-456.

Louwye, S., De Coninck, J. \& Verniers, J., 2000. Shallow marine Lower and Middle Miocene deposits at the southern margin of the North Sea Basin (northern Belgium): dinoflagellate cyst biostratigraphy and depositional history. Geological Magazine 137, 381-394.

Louwye, S., De Schepper, S., Laga, P. \& Vandenberghe, N., 2007. The Upper Miocene of the southern North Sea Basin (northern Belgium): a palaeoenvironmental and stratigraphical reconstruction using dinoflagellate cysts. Geological Magazine 144, 33-52.

McArthur, J.M., Howarth, R.J. \& Bailey, T.R., 2001. Strontium isotope stratigraphy: LOWESS Version 3. Best-fit line to the marine Sr-isotope curve for 0 to $509 \mathrm{Ma}$ and accompanying look-up table for deriving numerical age. Journal of Geology 109, 155-169.

McGowran, B., Li, Q. \& Moss, G., 1997. The Cenozoic neritic record in southern Australia: The biogeohistorical framework. [In:] N.P. James \& J.D.A. Clarke (Eds): Cool-water carbonates in space and time. SEPM, Special Volume 56, 185-203.

McGowran, B., Holdgate, G.R., Li, Q. \& Gallagher, S.J., 2004. Cenozoic stratigraphic succession in southeastern Australia. Australian Journal of Earth Sciences 51, 459-496.

Menning, M. \& Hendrich, A. (Eds), 2002. Stratigraphische Tabelle von Deutschland. Deutsche Stratigraphische Kommission, Potsdam, 1 pl.

Miller, K., Fairbanks, R.G. \& Mountain, G.S., 1987. Tertiary isotope oxygen isotope synthesis, sea level history and continental margin erosion. Paleoceanography 2,1-19.

Miller, K.G., Kominz, M.A., Browning, J.V., Wright, J.D., Mountain, G.S., Katz, M.E., Sugarman, P.J., Cramer, B.S., Christie-Blick, N. \& Pekar, S.F., 2005. The Phanerozoic record of global sea-level change. Science 310, 1293-1298.

Miller, K.G., Wright, J.D., Katz, M.E., Browning, J.V., Cramer, B.S., Wade, B.S. \& Misintzeva, S.F., 2008. A view of Antarctic ice-sheet evolution from sea-level and deep-sea isotope changes during the Late Cretaceous-Cenozoic. [In:] A.K. Cooper, P. Barrett, H. Stagg, B. Storey, E. Stump \& W. Wise (Eds): Antarctica: A key in a changing world. $10^{\text {th }}$ International Symposium on Antarctic Earth Sciences (Santa Barbara), 55-70.

Moreira, J.L.P., Madeira, C.V., Gil, J.A. \& Machado, M.A.P., 2007. Bacia de Santos. [Santos Basin]. Boletim de Geociências da Petrobras 15, 531-549.
Müller, R.D., Sdrolias, M., Gaina, C., Steinberger, B. \& Heine, C., 2008. Long-term sea-level fluctuations driven by ocean basin dynamics. Science 319, 1357-1362.

Murphy, M.A. \& Salvador, A., 1998. International stratigraphic guide - an abridged version. Episodes 22 , 255-271.

Ogg, J.G., Ogg, G. \& Gradstein, F.M., 2008. The concise geologic time scale. Cambridge University Press, Cambridge, 177 pp.

Ojeda, H.A.O., 1981. Estrutura, estratigrafia e evolução das bacias marginais brasileiras. [Structure, stratigraphy and evolution of the marginal Brazilian basins]. Revista Brasileira de Geociências 11, 257-273.

Oslick, J.S., Miller, K.G., Feigenson, M.D. \& Wright, J.D., 1994, Oligocene-Miocene strontium isotopes: stratigraphic revisions and correlation to an inferred glacioeustatic record. Paleoceanography 9, 427-444.

Pasley, M.A., Shepherd, D.B., Pocknall, D.T., Boyd, K.P., Andrade, V. \& Figueiredo, J.P., 2005. Sequence stratigraphy and basin evolution of the Foz do Amazonas Basin, Brazil. Search and Discovery Article \#10082.

Raju, D.S.N. (Ed.), 2007. Stratigraphic mega charts for the Indian subcontinent. International Commission on Stratigraphy, 2 pls.

Rosa, A.P., 2007. Interpretação sismo-estratigráfica da porção da Bacia de Pelotas que engloba o Cone do Rio Grande e a avaliação do seu potencial petrolifero. [Seismic-stratigraphic interpretation of the portion of the Pelotas Basin embracing the Rio Grande Cone and evaluation of its oil potential]. Ph.D. Thesis Universidade Estadual do Norte Fluminense.

Rossetti, D.F., 2001. Late Cenozoic sedimentary evolution in northerneastern Pará, Brazil, within the context of sea level changes. Journal of South American Earth Sciences 14, 77-89.

Ruban, D.A., 2007. Principal elements of the complex stratigraphical analysis of oil-gas-bearing basins. Stratigraphy and sedimentology of oil-gas basins 1, 20-27.

Ruban, D.A., Zerfass, H. \& Pugatchev, V.I., 2009. Triassic synthems of southern South America (southwestern Gondwana) and the Western Caucasus (the northern Neotethys), and global tracing of their boundaries. Journal of South American Earth Sciences 28, 155-167.

Ruban, D.A., Zorina, S.A. \& Conrad, C.P., 2010. No global-scale transgressive-regressive cycles in the Thanetian (Paleocene): Evidence from interregional correlation. Palaeogeography, Palaeoclimatology, Palaeoecology 295, 226-235.

Ruban, D.A., Zorina, S.A., Conrad, C.P. \& Afanasieva, N.I., 2012. In quest of Paleocene global-scale transgressions and regressions: constraints from a synthesis of regional trends. Proceedings of the Geologists' Association 123, 7-18.

Sacchi, M., Horvath, F. \& Magyari, O., 1999. Role of unconformity-bounded units in the stratigraphy of the continental record: a case study from the Late Miocene of the western Pannonian basin, Hungary. [In:] B. Durand, L. Jolivet, F. Hovarth \& M. Seranne (Eds): The Mediterranean basins: Tertiary extension within the Alpine orogen. Geological Society, London, Special Publication 156, 357-390. 
Salvador, A., 1987. Unconformity-bounded stratigraphic units. Geological Society of America Bulletin 98, 232-237.

Salvador, A. (Ed), 1994. International stratigraphic guide - a guide to stratigraphic classification, terminology, and procedure. International Subcommission on Stratigraphic Classification, Geological Society of America, 214 pp.

Salvador, A., 2003. Review of the concepts and recommended terminology for unconformity-related units. International Subcommission on Stratigraphic Classification, Newsletter 1, 17-19.

Schmitz, B., Molina, E. \& v. Salis, K., 1998. The Zumaya section in Spain: A possible global stratotype section for the Selandian and Thanetian Stages. Newsletters on Stratigraphy 36, 35-42.

Scotese, C.R., 2004. A continental drift flipbook. Journal of Geology 112, 729-741.

Shackleton, N.J. \& Kennett, J.P., 1975. Paleotemperature history of the Cenozoic and the initiation of Antarctic glaciation: oxygen and carbon isotope analyses in DSDP Sites 277, 279, and 281. Initial Reports of the Deep Sea Drilling Project 29, 743-755.

Shackleton, N.J. \& Hall, M.A., 1984. Carbon isotope data from Leg 74 sediments. Initial Reports of the Deep Sea Drilling Project 74, 613-619.

Sharland, P.R., Archer, R., Casey, D.M., Davies, R.B., Hall, S.H., Heward, A.P., Horbury, A.D. \& Simmons, M.D., 2001. Arabian Plate sequence stratigraphy. GeoArabia Special Publication 2, 1-371.

Shimabukuro, S., 1994. "Braarudosphaera chalk": investigações sobre a gênese de um marco estratigráfico. ["Braarusphaera chalk": investigation on the genesis of a stratigraphic mark]. M.Sc. Thesis Universidade Federal do Rio Grande do Sul.

Simmons, M.D., Sharland, P.R., Casey, D.M., Davies, R.B. \& Sutcliffe, O.E., 2007. Arabian plate sequence stratigraphy: potential implications for global chronostratigraphy. GeoArabia 12, 101-130.
Soto, M., Morales, E., Verolavsky, G., Santa Ana, H. \& Ucha, N., 2011. The continental margin of Uruguay: crustal architecture and segmentation. Marine and Petroleum Geology 28, 1676-1689.

Swezey, C.S., 2009. Cenozoic stratigraphy of the Sahara, Northern Africa. Journal of African Earth Sciences 53, 89-121.

Vail, P.R. \& Hardenbol, J., 1979. Sea level changes during Tertiary. Oceanus 22, 71-79.

Viana, A.R., Castro, D.D. \& Kowsmann, R.O., 1990. A discordância do Mioceno médio superior: um marco regional no talude da Bacia de Campos. [The Upper Middle Miocene discordance: a regional mark in the slope of the Campos Basin]. Congresso Brasileiro de Geologia, 1990, Anais. Curitiba, 313-333.

Walsh, S.L., 2004. Solutions in chronostratigraphy: the Paleocene/Eocene boundary debate, and Aubry vs. Hedberg on chronostratigraphic principles. Earth-Science Reviews 64, 119-155.

Wigley, R.A. \& Compton, J.S., 2006. Late Cenozoic evolution of the outer continental shelf at the head of the Cape Canyon, South Africa. Marine Geology 226, 1-23.

Winter, W.R., Jahnert, R.J., França, A.B., 2007. Bacia de Campos. [Campos Basin]. Boletim de Geociências da Petrobras 15, 511-529.

Zachos, J.C., Dickens, G.R. \& Zeebe, R.E., 2008. An Early Cenozoic perspective on greenhouse warming and carbon-cycle dynamics. Nature 451, 279-283.

Zachos, J., Pagani, M., Sloan, L., Thomas, E. \& Billups, K., 2001. Trends, rhythms, and aberrations in global climate 65 Ma to present. Science 292, 686-693.

Zalasiewicz, J. \& Williams, M., 2012. The Goldilocks planet - the four billion year story of Earth's climate. Oxford University Press, Oxford, 303 pp.

Manuscript submitted 10 December 2012 Revision accepted 17 June 2013 